\title{
Evaluation Index System for Green Development of Textile and Garment Industry
}

\author{
Chengzhi Niu ${ }^{1}$, Yougan $\mathrm{Zhu}^{1, *}$ \\ ${ }^{1}$ Beijing Institute of Fashion Technology, Chaoyang District, Beijing, 100020, PRC
}

\begin{abstract}
This article uses the analytic hierarchy process to establish the textile industry green development evaluation index system. This index system supplements the existing textile industry green development evaluation system research to a certain extent, enriches the existing industry evaluation research, and further expands Vision and ideas for the development of the textile industry. This indicator system can help the textile and apparel industry to understand the transformation stage of the industry more reasonably in the green development, and help the textile and apparel industry to achieve a green and sustainable development transformation.
\end{abstract}

\section{Introduction}

The advent of the new century has brought China into a critical stage of rapid development of industrialization, urbanization and agricultural modernization. [1] The unsustainable development methods caused by traditional industrial production models have made environmental pollution problems more and more serious. With the increasingly prominent contradiction between economic development and the environment, energy conservation and emission reduction have become a key task in transforming the economic development mode. [2]

Under the huge challenges of resource and environmental constraints, accelerating the structural adjustment and transformation of the textile industry and improving the level of energy conservation and emission reduction are important ways for the textile industry to enhance the overall value, enhance the ability to resist risks, and maintain long-term vitality.

\section{Construction of Green Development Index System of Textile and Garment Industry}

\subsection{Characteristics of the Textile Industry}

Due to the continuous improvement of product environmental protection requirements in countries around the world in recent years, China's textile and apparel industry is facing operational difficulties. From the figure, we can see that China's textile industry prosperity index has been on a downward trend since 2012.

The industry needs to undergo industry transformation to realize the industry's further development. In the transformation of the textile and apparel industry, green environmental protection will be the main task of the transformation. Next, we aim at the characteristics of the textile and apparel industry to find a green development path suitable for the apparel and textile industry.

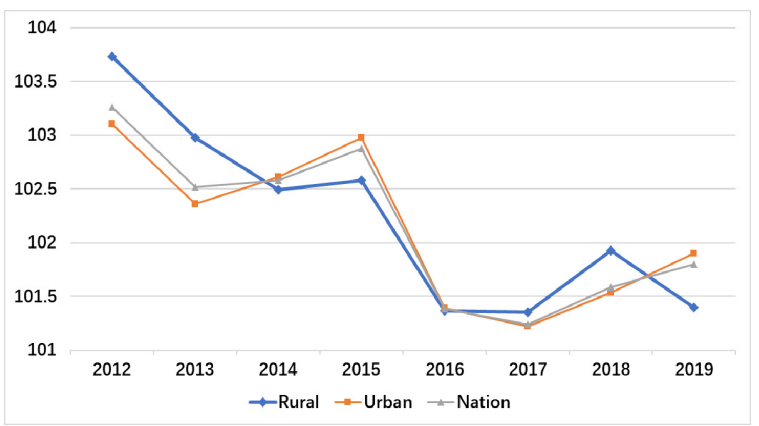

Fig. 1. Textile and Apparel Industry Prosperity Index

\subsubsection{Strong industry foundation}

The textile and garment industry are one of the pillar industries of China's national economy. At present, China's textile and garment production capacity ranks first in the world. China has become the world's largest textile and garment producer. The Pearl River Delta and the Yangtze River are the centre of China's textile industry. [3] Shanghai is China's largest textile and garment foreign trade port city and textile industrial base. The two deltas have led the development of China's textile and garment industry. The industrial clusters of the textile industry and the textile professional market together constitute the production mode of the modern textile industry.

And since the 1980s, textiles and clothing have always been China's first export commodities, and their exports accounted for about one-fourth of China's total

\footnotetext{
* Corresponding author: macrov@yeah.net
} 
merchandise exports. The growth rate of China's textile and apparel exports is also significantly higher than the world's growth rate, and it has quickly surpassed the world's major textile and apparel exporters such as Italy and Germany to become the world's number one textile and apparel exporter.

\subsubsection{High energy consumption and serious pollution}

The green ecological development of China's textile and clothing industry is insufficient. In the textile industry, the sewage discharge of the printing and dyeing industry has accounted for $60 \%$ of the sewage discharge of the textile industry, and it has become the fifth largest discharger of sewage in the Chinese manufacturing industry. The energy consumption of the textile and chemical fibre industry is $10 \%$ higher than the advanced level of the foreign industry. As the country further strengthens environmental protection, production and investment activities in some small and medium-sized industries have been restricted. In the future, the textile industry must solve the problems of high energy consumption and high pollution in the high-quality development.

\subsubsection{Lack of green technology}

The environmental protection level of China's textile and apparel industry is not high. As we all know, weaving, dyeing and finishing, design, and sewing are the four steps of textile production, and each step has certain requirements for environmental protection technology. China's textile production industry is mainly in the steps of weaving and sewing, which makes Chinese textiles more labour-intensive. The developed countries rely on their abundant capital and advanced technology to transform the textile industry with high-tech, so that the originally labour-intensive textile industry has embarked on a capital-technological road. Their products contain more capital and technical factors, and are more able to adapt to the demand for high-grade, comfortable and safe textiles arising from green consumption. Although from 1997 to 1999, China optimized the industry structure and product structure of the textile industry by compressing and eliminating obsolete equipment and introducing advanced textile printing, dyeing, finishing and ironing equipment. There is a big gap in environmental protection standards. China's textile and apparel industry has insufficient motivation for green technology innovation. Some industries in China's textile and apparel industry also adopt the business model of OEM and low-end manufacturing, which are at the low end of the production value chain, and the added value of products is not high. In export trade, the current apparel industry still wins by volume, and the average price of a single product is low. The ability to innovate in green technology is not strong, the core environmental protection technology is incomplete, the level of technological application in the industry varies greatly, and the overall development level of the industry green technology is not high enough.

\subsection{Construction Index System for Green Development of Textile and Garment Industry}

The technological processes in the textile industry almost all pollute the environment. Realizing the green of the textile technological processes through new technological processes is an indispensable part of green development. [4] The green process will greatly save energy consumption, sewage discharge and improve the recycling rate of pollutants. In this paper, indicators such as the degree of green clean production, the utilization rate of wastewater, and the utilization rate of solid waste are selected as the evaluation indicators from the perspective of green technology.

The perspective of green technology innovation is set up by the textile industry to meet the challenges of green production. It aims to improve the competitiveness of green technologies, continuously launch innovative products or use innovative green technologies for production. Only by realizing sustainable green technological innovation can China's textile products meet ecological or green requirements and realize the sustainable development of environmental protection and resource conservation. This paper selects indicators such as the investment ratio of environmental protection equipment, the ratio of environmental benefits and the amount of green technology as the evaluation indicators from the perspective of green technology innovation.

Green development is inseparable from the internal governance of the textile industry. The pollutants generated during the manufacturing process of the textile industry have brought serious harm to the environment. Strengthening the green governance of the textile industry will help the industry fulfil relevant laws and regulations and help the industry establish Awareness and culture of green development. This paper selects indicators such as the number of environmental protection certifications, the amount and frequency of major environmental violations, and the amount of pollution control for evaluation.

This article summarizes the industry's green development indicators as follows: environmental pollution and resource consumption include operating income $\mathrm{SO}_{2}$ emissions, operating income water consumption, energy-saving emission reduction plans, etc., green processes include green and clean production, wastewater utilization, solid waste Utilization rate, etc. Green technology innovation includes environmental protection equipment investment ratio, environmental income ratio and green technology volume, etc. Green governance includes the number of environmental protection certifications, the amount and frequency of major environmental violations, and the amount of pollution control. 


\section{Calculation of index weights based on the Analytic Hierarchy Process}

The analytic hierarchy process is a complex multiobjective decision-making system. It decomposes the goal into multiple goals or criteria, and further decomposes the goal into multiple indicators. It uses the quantification method to calculate the hierarchy order to optimize decision-making. From the discussion in Chapter 2, we have established the following indicator system.

Table 1. The hierarchical model of Green Development Index System for Textile and Garment Industry

\begin{tabular}{|c|c|c|}
\hline Target layer & $\begin{array}{c}\text { Criterion } \\
\text { layer }\end{array}$ & Indicator layer \\
\hline \multirow{16}{*}{$\begin{array}{c}\text { Index } \\
\text { System for } \\
\text { Green } \\
\text { Developmen } \\
\mathrm{t} \text { of Textile } \\
\text { and Garment } \\
\text { Industry A }\end{array}$} & \multirow{4}{*}{$\begin{array}{c}\text { Environment } \\
\text { al pollution } \\
\text { and energy } \\
\text { consumption } \\
\text { B1 }\end{array}$} & $\mathrm{SO} 2$ emissions $\mathrm{C} 1$ \\
\hline & & Water consumption $\mathrm{C} 2$ \\
\hline & & $\begin{array}{l}\text { Pollution reduction indicators } \\
\qquad \mathrm{C} 3\end{array}$ \\
\hline & & $\begin{array}{l}\text { Energy saving and emission } \\
\text { reduction plan C4 }\end{array}$ \\
\hline & \multirow{4}{*}{$\begin{array}{c}\text { Environment } \\
\text { al protection } \\
\text { process B2 }\end{array}$} & $\begin{array}{l}\text { Green and clean production } \\
\text { C5 }\end{array}$ \\
\hline & & $\begin{array}{c}\text { Wastewater utilization rate } \\
\text { C6 }\end{array}$ \\
\hline & & $\begin{array}{c}\text { Solid waste utilization rate } \\
\text { C7 }\end{array}$ \\
\hline & & $\begin{array}{c}\text { Green production process } \\
\text { certification } \mathrm{C} 8 \\
\end{array}$ \\
\hline & \multirow{4}{*}{$\begin{array}{c}\text { Green } \\
\text { technology } \\
\text { innovation } \\
\text { B3 }\end{array}$} & $\begin{array}{c}\text { Environmental protection } \\
\text { equipment investment ratio } \\
\text { C9 } \\
\end{array}$ \\
\hline & & $\begin{array}{c}\text { Environmental benefit ratio } \\
\mathrm{C} 10\end{array}$ \\
\hline & & $\begin{array}{c}\text { Green technology volume } \\
\mathrm{C} 11\end{array}$ \\
\hline & & $\begin{array}{l}\text { Green production efficiency } \\
\text { C12 }\end{array}$ \\
\hline & \multirow{4}{*}{$\begin{array}{c}\text { Green } \\
\text { governance } \\
\text { B4 }\end{array}$} & $\begin{array}{c}\text { Number of environmental } \\
\text { certifications } \mathrm{C} 13\end{array}$ \\
\hline & & $\begin{array}{c}\text { Major environmental } \\
\text { violation amount } \mathrm{C} 14\end{array}$ \\
\hline & & $\begin{array}{c}\text { Number of major } \\
\text { environmental violations } \mathrm{C} 15\end{array}$ \\
\hline & & $\begin{array}{l}\text { Amount of sewage treatment } \\
\text { C16 }\end{array}$ \\
\hline
\end{tabular}

We have invited many experts to revise the indicator system and give scores. These experts include professors and scholars from Beijing Institute of Fashion Technology, as well as senior managers in Chinese textile and garment industry.

The judgement matrix was constructed by using the Delphi Method. The Delphi method will investigate the opinions of experts on the questions raised in the questionnaire in multiple rounds. This method is reliable in the research field.

Before analysing the indicators of Analytic Hierarchy Process, we need to check their consistency first.

We use the consistency index CI and the ratio CR to check the consistency. When $\mathrm{CR}<0.1$, it indicates that the judgment matrix has passed the consistency test; otherwise, the judgment matrix should be corrected.
The calculation process of the consistency index is as follows:

Table 2. The A-B Judgment Matrix

\begin{tabular}{|c|c|c|c|c|}
\hline A & B1 & B2 & B3 & B4 \\
\hline B1 & 1 & 3 & 3 & 2 \\
\hline B2 & $1 / 3$ & 1 & $1 / 3$ & $1 / 4$ \\
\hline B3 & $1 / 3$ & 3 & 1 & $1 / 3$ \\
\hline B4 & $1 / 2$ & 4 & 3 & 1 \\
\hline
\end{tabular}

Table 3. The B2-C Judgment Matrix

\begin{tabular}{|c|c|c|c|c|}
\hline $\mathrm{B} 1$ & $\mathrm{C} 1$ & $\mathrm{C} 2$ & $\mathrm{C} 3$ & $\mathrm{C} 4$ \\
\hline $\mathrm{C} 1$ & 1 & $1 / 3$ & 1 & $1 / 4$ \\
\hline $\mathrm{C} 2$ & 3 & 1 & 5 & 2 \\
\hline $\mathrm{C} 3$ & 1 & $1 / 5$ & 1 & $1 / 2$ \\
\hline $\mathrm{C} 4$ & 4 & $1 / 2$ & 2 & 1 \\
\hline
\end{tabular}

Table 4. The B2-C Judgment Matrix

\begin{tabular}{|c|c|c|c|c|}
\hline B2 & C5 & C6 & C7 & C8 \\
\hline C5 & 1 & 3 & 1 & $1 / 3$ \\
\hline C6 & $1 / 3$ & 1 & $1 / 2$ & $1 / 5$ \\
\hline C7 & 1 & 2 & 1 & $1 / 5$ \\
\hline C8 & 3 & 5 & 5 & 1 \\
\hline
\end{tabular}

Table 5. The B3-C Judgment Matrix

\begin{tabular}{|c|c|c|c|c|}
\hline B3 & C9 & C10 & C11 & C12 \\
\hline C9 & 1 & 4 & 2 & $1 / 3$ \\
\hline C10 & $1 / 4$ & 1 & $1 / 3$ & $1 / 3$ \\
\hline C11 & $1 / 2$ & 3 & 1 & $1 / 3$ \\
\hline C12 & 3 & 3 & 3 & 1 \\
\hline
\end{tabular}

Table 6. The B4-C Judgment Matrix

\begin{tabular}{|c|c|c|c|c|}
\hline B4 & C13 & C14 & C15 & C16 \\
\hline C13 & 1 & 4 & $1 / 2$ & 3 \\
\hline $\mathrm{C} 14$ & $1 / 4$ & 1 & $1 / 4$ & $1 / 2$ \\
\hline $\mathrm{C} 15$ & 2 & 4 & 1 & 4 \\
\hline $\mathrm{C} 16$ & $1 / 3$ & 2 & $1 / 4$ & 1 \\
\hline
\end{tabular}

The maximum eigenvalues $\lambda$ max obtained in the A-B judgment matrix is 4.2106 , test coefficient is $\mathrm{CR}=\mathrm{CI} / \mathrm{RI}=0.0789<0.1$ we can see that the result has passed the test. The weight the matrix is $(0.431,0.3235,0.1591,0.0865)^{\mathrm{T}}$.

The maximum eigenvalues $\lambda$ max obtained in the B-C judgment matrixes are 4.1112, 4.0788, 4.2427, 4.0813, and the test coefficients CR are 0.0416, 0.0295, 0.0909, 0.0304 . The four CR are less than 0.1 , we can see that all the judgment matrix passes the consistency test. The weight of the indicator layer is shown in Table 7.

Table 7. Textile and Garment Industry Green Development Index System Weight Table

\begin{tabular}{|c|c|c|}
\hline Criterion Layer & Indicator Layer & $\begin{array}{c}\text { Relative } \\
\text { Weight }\end{array}$ \\
\hline Environmental & SO2 emissions & $20.69 \%$ \\
\hline
\end{tabular}




\begin{tabular}{|c|c|c|}
\hline \multirow{3}{*}{$\begin{array}{l}\text { pollution and } \\
\text { energy } \\
\text { consumption } \\
43.1 \%\end{array}$} & Water consumption & $15.43 \%$ \\
\hline & $\begin{array}{c}\text { Pollution reduction } \\
\text { indicators } \\
\end{array}$ & $12.68 \%$ \\
\hline & $\begin{array}{c}\text { Energy saving and } \\
\text { emission reduction plan }\end{array}$ & $10.06 \%$ \\
\hline \multirow{4}{*}{$\begin{array}{c}\text { Environmental } \\
\text { protection process } \\
32.25 \%\end{array}$} & $\begin{array}{c}\text { Green and clean } \\
\text { production }\end{array}$ & $7.65 \%$ \\
\hline & $\begin{array}{c}\text { Wastewater utilization } \\
\text { rate }\end{array}$ & $4.94 \%$ \\
\hline & $\begin{array}{l}\text { Solid waste utilization } \\
\text { rate }\end{array}$ & $4.91 \%$ \\
\hline & $\begin{array}{c}\text { Green production } \\
\text { process certification }\end{array}$ & $4.82 \%$ \\
\hline \multirow{4}{*}{$\begin{array}{c}\text { Green technology } \\
\text { innovation } \\
15.19 \%\end{array}$} & $\begin{array}{c}\text { Environmental } \\
\text { protection equipment } \\
\text { investment ratio }\end{array}$ & $4.17 \%$ \\
\hline & $\begin{array}{c}\text { Environmental benefit } \\
\text { ratio }\end{array}$ & $4.12 \%$ \\
\hline & $\begin{array}{c}\text { Green technology } \\
\text { volume }\end{array}$ & $2.74 \%$ \\
\hline & $\begin{array}{c}\text { Green production } \\
\text { efficiency }\end{array}$ & $2.71 \%$ \\
\hline \multirow{4}{*}{$\begin{array}{c}\text { Green governance } \\
8.65 \%\end{array}$} & $\begin{array}{c}\text { Number of } \\
\text { environmental } \\
\text { certifications } \\
\end{array}$ & $1.66 \%$ \\
\hline & $\begin{array}{c}\text { Major environmental } \\
\text { violation amount }\end{array}$ & $1.39 \%$ \\
\hline & $\begin{array}{c}\text { Number of major } \\
\text { environmental violations }\end{array}$ & $1.33 \%$ \\
\hline & $\begin{array}{c}\text { Amount of sewage } \\
\text { treatment }\end{array}$ & $0.72 \%$ \\
\hline
\end{tabular}

\section{Conclusion}

From the above indicator system, we draw the following conclusions and recommendations for the green development of Chinese textile and garment industry:

Establish and standardize an environmental management system and a textile and clothing safety standard system. In the face of green trade barriers, the domestic export industry should strengthen the quality management in the production and processing of export textiles and garments. The textile and garment industry should actively establish and implement an environmental management system in order to develop ecological textiles for the industry and implement green marketing strategies. The textile and garment industry must gradually eliminate toxic raw materials, reduce the amount of waste, and use safe, hygienic, harmless, nonpolluting, energy-saving fabrics and auxiliary materials, so that the entire production process of products meets specific environmental protection standards.

We must incorporate environmental factors into brand design, packaging design and the services provided to guide consumer trends, establish a good industry image, and form an atmosphere of advocating nature and proud of the production and use of ecological textiles in the whole society.

China's textile and garment industry should adjust its product development strategy, vigorously develop environmentally friendly products, and take green textiles and ecological clothing as new growth points for exports. At present, international green textiles have multiple functions such as deodorization, antibacterial, and UV resistance.

The textile and garment industry should use clean technology and change the traditional production method into a cleaner production method. Clean technology refers to technology that can reduce or prevent pollution or no waste. The textile industry is a typical chemical production industry with various possible pollution channels. To block these channels requires strengthening of environmental management.

The textile and apparel industry should strive to achieve green product packaging. Green packaging is becoming a compelling and effective part of green marketing. Therefore, the importance of promoting green packaging is increasing. The green packaging of packaging can undoubtedly convey green information to consumers most directly and establish the image of green products in the eyes of the public. Therefore, green packaging is undoubtedly of great significance to the smooth implementation of green marketing. Green packaging is mainly manifested in: reducing product packaging, using reusable packaging materials, using packaging made of degradable materials, and so on.

In the context of environmental protection, this article aims at the new requirements of the textile industry's green development and establishes a performance evaluation index system for the textile industry's green development. This indicator system provides certain guidance and enlightenment for the green transformation and improvement of the textile industry, scientifically evaluates energy consumption and pollution, and reasonably formulates strategic goals to achieve sustainable green development of the textile and apparel industry.

\section{Acknowledgement}

This research was financially supported by the nongovernment sponsored scientific research projects about Enhancement of the capabilities of China's Certified Public Valuer from the perspective of new standards of the Graduate School of Beijing Institute of Fashion Technology (Grand NO. HXKY05200310).

\section{References}

1. Huang P S, Shih L H. Effective Environmental Management through Environmental Science and Technology $[\mathrm{J}]$. European Journal of Operational Research ,2009,6(1): 5-50 .

2. Ranganatha, Ditzd. Global developments on environment performance indicators[J]. Transportation Research Part E, 2002, 38(5): 281303.

3. Yongqiang Gao. Corporate Social Performance in China: Evidence from Large Companies[J]. Journal of Business Ethics ,2009,89(3):23-35.

4. Michael E. Porter, Vander Linde, Claas. Toward a New Conception of the Environment[J]. Journal of Economic Perspectives, 1995,131(9): 97-118. 